\title{
A Review of the Fundamentals of Corporate Social Responsibility
}

\author{
Mallick Rakibul Hasan ${ }^{1}$ Shahriar Parvin ${ }^{2}$ Marjana Jahir $^{3}$ Sumaiya Sultana ${ }^{4}$
}

\author{
1. Department of Business Administration, BGMEA University of Fashion \& Technology (BUFT), Bangladesh \\ 2. Department of English, BGMEA University of Fashion \& Technology (BUFT), Bangladesh \\ 3. Department of English, BGMEA University of Fashion \& Technology (BUFT), Bangladesh \\ 4. Department of Fashion Design \& Technology, BGMEA University of Fashion \& Technology (BUFT), \\ Bangladesh
}

\begin{abstract}
The objective of this review paper is to accommodate the fundamental concepts of the recent burning term "Corporate Social Responsibility" in a single article. Actually this term is an olden topic of discussion. But with the changes of time the definition, scope and features of the concept have changed to a significant level. But it is a consensus opinion that an universal definition of CSR is still absent and according to few scholars it words as one of the most important barriers towards the runway to the successful and wide implementation of CSR. According to some intellectuals corporate social responsibility is a voluntary contribution of the corporations which contribute to the development of people, planet and profit while someone added stakeholders and philanthropy with those three components. This contemporary phase demands that the corporation should practice CSR vigorously as because practicing CSR will not only endorse and secure profit for the organization through increasing its competitiveness, competencies and attractiveness, but also will build long term customer satisfaction, branding image and the reputation as a socially responsible actor. And so the recent researches reveal that the present environmental condition, customers, government, NGO's, workers organization and the global competition itself are now claiming CSR undertakings from the companies and few international laws and conventions have already in action to support this entitlement. So, practicing CSR is not an option now for the companies.
\end{abstract}

Keywords - Corporate Social Responsibility, Fundamental concepts of CSR, Companies.

\section{OBJECTIVES:}

The objective of this paper is to reconcile all the basic fundamental concepts pertaining to corporate social responsibility in a single paper in order to give the audience an accumulated knowledge of corporate social responsibility.

\section{METHODOLOGY:}

This is completely a review paper and as a result of this all the data used in this paper are from secondary sources. Published articles in different national and international journals are used as secondary sources of data. We have selected those published articles which explain CSR and different aspects of CSR. This paper is mainly an accretion of the CSR related indispensable theories.

\section{INTRODUCTION:}

The primary objective of every company is to maximize the profits and the shareholders wealth. But at the same time, if we think about social object then it is the responsibility of every company to provide pollution free environment, improved quality products, less wastage of natural resources and human resource development. The recent focus of the corporations is to undertake CSR activities as a means of their new business function in order to satisfy every stakeholder. Corporate social responsibility is more a new concept or idea now. These days CSR is considered to be an important activity of the corporations in this globalized world. Even not only the corporations, but the consumers are now demanding products which are produced in socially responsible companies (Chopra et al., 2014). So, actually now the practice of CSR has become a demanding constituent by all the stakeholders. The activities under the banner of corporate social responsibility include investment in community development, keeping better employee relations, maintaining employment and environmental responsibility, human rights and so on. It is all about producing and delivering environmentally friendly products and services to the society and to the country at large. And the company should establish an equitable and ethical employment and it is considered asstrategic social investment. CSR is a collection of business policies developed by the companies to do business with the stakeholders by keeping safe the natural 
affairs. (Waddock, 2004). CSR is a set of initiatives in the organization that appear to contribute to the promotion of social good by broadening the goals of key stakeholder groups beyond compliance with existing rules and regulations (Waldman et al. 2006a, Waldman \& Siegel, 2008).CSR has gained business renown due to the actions of pressure groups and also the emergence of the "market for virtues" such as Socially Responsible Investment (SRI) that create further pressures to adopt CSR initiatives.(Chopra et al., 2014). The trend of CSR is changing both the social attitudes of the organizations towards their responsibilities. Now the firms are not only concerned about their financial performance, but also their social and ecological performance. Transparency, accountability and human right are some of the key issues now. Corporate social responsibility activities are manifest in organizational programs that protect and improve societal welfare, ranging from cause-related marketing, employee benefits, community outreach, to eco-friendly or sustainable business practices. (Du et al 2013).Corporate social responsibility has become a center of discussion for the companies. Even the economist devoted a special issue to denouncing it earlier this year.

\section{DEFINITION OF CSR}

A fundamental problem in the field of corporate social responsibility (CSR) is that there is no universally accepted definition of the concept (Sriramesh et al. 2007, Nasrullahet al., 2014 and Industry Canada, 2009:1). In this junction Matten and Moon thinks CSR is a vague idea, having no specific meaning (Matten and Moon, 2005). Focusing on the obscure side of CSR, it is significant for the responsibilities of the corporation towards the stakeholders in relation to the triple concepts of 'people, planet, and profit' (Crook, 2005, Cramer et al. 2006 \&Elkington, 2004). It is not easy to define CSR within a limited context; it varies from one perception to another depending on the theme that business ethics should secure the societal benefit. (Campbell, 2007; Matten and Moon, 2008)The field has evolved assuming different names such as corporate social responsiveness (in the 1970s) and corporate social performance (in the 1980s). But still the scholars have not stopped themselves from giving their opinions. At first Friedman characterizes CSR as a profit making vehicle but being with the law of the game. For Friedman, CSR is pictured as a means of increasing or maximizing the profits of the company where the shareholders are the focal point in pursuit of profit maximization. Freeman mentioned CSR is only about caring the stakeholders and Donaldson identified CSR as interdependency between social, people and organization and along with them Ward analyzes that CSR is a practice to organize the cost and benefits of a company to do business with its different stakeholder's like-workers, shareholders, customers, suppliers and others. (Ward, 2004)But in contemporary context CSR is not such a narrow concept and it had started to be felt by Carroll in 2000. Carroll clarifies CSR as what society expects lawfully, morally and discretionarily from a business organization at any point in time (Carroll, 2000). In connection with Carroll, Maignan and Ferrell define that CSR is the degree that the stakeholders make compulsory for the businesses to maintain the economic, lawful, moral and discretionary obligations (Maignan and Ferrell, 2001).CSR is companies' charitable business policies where they think about social and environmental issues while interacting with the stakeholders. (EU, 2002) and in the same way CSR is what an organization donates to uphold the society by strengthening the business objectives with different stakeholders. (McWilliams \& Siegel, 2000, Waldman \& Siegel, 2008).Matten and Moon (2005, 2008) classified CSR into 'implicit' approach and 'explicit' approach. Implicit CSR is derived from a rigorous ethical principle and circulates in the chain relationship among business, society and government. It is that moral obligation which every corporation must follow for facing their stakeholder issue \& explicit CSR is a voluntary service of the corporations to show their devotion towards the society in a systematic way and the definition of the European Commission describes that in CSR companies follows certain business policies, as a deliberate effort to state its dedication for the betterment of society and environment. (European Commission, 2001).CSR works for the sustainable development of a society. In its management it looks after the financial, ecological and social sides of a business to bring a fruitful result in society. (OECD, 2001 and Schaltegger \& Burritt, 2005). So finally we can say that CSR is a voluntary involvement of the organizations which will uphold the societal, environmental and organizational wellbeing.

\section{IMPORTANCE OF PRACTICING CSR}

CSR has never been more prominent on the corporate agenda than it is today. Nowadays CSR is playing an important role in the fast universal changes. Customers are more cautious and concern about the products that they are purchasing and companies are also becoming more responsible about the products that they are manufacturing, supplying and selling. The reasons behind these responsible activities are based on consumer demand, legal requirements that are developing rapidly in the last decade and, the competing requirements of the firms.Firms that are triggered by the goals of achieving better corporate reflection, branding, and prosperity to carry out CSR activities are likely to emphasize firm-level outcomes in their assessment of the results of their CSR practices. They will recognize CSR as synonymous with corporate social investments (CSIs). Firms that are inspired by humanitarian concerns will place greater premium on the societal outcomes of 
their practices (Kuada, John, and Robert E. Hinson 2012).Most multinational corporations (MNCs) recognize corporate social responsibility (CSR) as a business tool to promote a positive image to business stakeholders. Several scholars have investigated the impact of businesses' CSR initiatives on their key stakeholders. McDonald and Rundle-Thiele argue that successful practices of CSR may move up the extent of satisfaction of the bank customers (McDonald and Rundle-Thiele, 2008). Calabrese and Lancioni talks about the impact of CSR practices on employee as well as customer satisfaction in service companies (Calabrese and Lancioni, 2008). The recent researches in the ground of CSR illustrate that the top benefits were related to customers and employees, who were also the most significant stakeholders identified as because the corporations are enjoying a more consistent employees, improved image, and reduced business costs as a result of CSR practices.CSR practice can contribute to the eradication of one of the impactful social evil 'poverty'. Now the MNCs consider climate change as the key international and local problem that they must actively engage in because it poses potentially serious risks and may lead to long-term poverty, not only to the host countries, but also to their clients and partners worldwide (Pimpa and Nattavud, 2011). In recent times, the international business community increasingly has used the concept of CSR to establish a framework for broader private sector involvement in poverty alleviation (WBCSD, 2002).It is widely discussed that the practice of CSR will not only contribute to the society and environment, but also will provide and sustainable return to the company. Bodwell et al. justifies through their research that the relationship between CSR practice of the company and financial performance of the company is apparently positive (Bodwell, Graves, \&Waddock, 2002). CSR practices, such as the introduction of systems to improve performance, the implementation of environmental management systems and coverage, and the benefaction to employees' value of life as well as contribution of society, may possibly initiate encouraging outcomes regarding corporate image and reputation as a socially dependable firm, mostly to the investors, suppliers and customers of the institution with the ensuing constructive results in market performance, access to capital markets, and profit (McWilliams \& Siegel, 2001, Waldman et al. 2006a, Adam \&Shavit 2008). The framework of CSR facilitates the organizations to be environmentally and socially compliant and which will eventually benefit the organization from financial perspective. CSR enables a firm to appeal to the socio-cultural rules of its institutional atmosphere and subsidize to its social authenticity (Handelman and Arnold, 1999; Palazzo and Scherer, 2006). In turn, social legitimacy ensures the continuity of the resources and perennial support from the internal and external stakeholders of the firm (Palazzo and Scherer, 2006; Sen and Bhattacharya, 2001).

\section{BARRIERS OF CSR}

We are well aware about the positive gains of the companies for practicing CSR. Many of the global and well reputed organizations are now not only thinking, but also practicing CSR in their business operations and enjoying positive reputational and economical gain. But it is also true that a lot of companies still has not yet been started to think about this crucial and powerful issue and many of them are also there who want to practice CSR, but few barriers are restraining them from the implementation. It has already been mentioned by several scholars repeatedly that the concept of CSR is still unclear and does not have any obvious description, which can stand for as the most important barrier from implementing CSR. Tudev argues that the fundamental problem which is continuing is that there is no definition of social responsiveness which provides a perfect structure of achievement; the concept of social responsiveness conveys no distinct meaning for citizens, managers, or employees, which seriously confines its usefulness in practice. (Tudev et al. 2011)Inyang illustrated that there are few barriers or constraints associated with adoption and implementation of CSR by SMEs which includes the cost of implementing CSR, time constraint, limited knowledge among a large spectrum of SMEs, lack of awareness of the benefits of CSR, SMEs lack of capacity to collect and analyze useful data in sustainable development, no systematic incentives or frameworks, lack of information on CSR activities, existing CSR tools and guidelines are of little or no relevance to SMEs, SMEs lack adequate support services and fear of additional regulatory and bureaucratic burdens(Inyang, 2013)The negative or one eyed mentality of the managers, owners and leaders of the organization may hinder the CSR performance. Massoud argued that the barriers toward the implementation of the CSR may cause due to the personal characteristics of owners or the organizational characteristics of the firm (Massoud, 2010).

\section{DRIVERS OF CSR}

Firms effort to reply to different demands from diverse stakeholders, organizing from employees, customers, suppliers, and society to media, NGOs and governments (McWilliams and Siegel, 2001; Ditlev Simonsen and Midttun, 2011).The key drivers connected with CSR can be separated into the following groups: stakeholder needs, performance, and motivation (Basu and Palazzo, 2008).Stakeholders are considered in this recent word as biggest driver of CSR. CSR as the range to which businesses meet the economic, legal, ethical and discretionary responsibilities destined on them by stakeholders (Maignan and Ferrell, 2001). Along with them Young and Rivers states that the MNEs are feeling pressure for their subsidiaries not only from their home 
country stakeholders, but also from the host country stakeholders. Another significant factor of stakeholders which is driving the thought of CSR among MNCs is institutional commitment with stakeholders. The stakeholder theory point out that 'it can be helpful for the firm to set in particular CSR performance that nonfinancial stakeholders separated to be important, as, without this, these groups can take back their support for the firm' (McWilliams et al., 2006).CSR is not only driven by the stakeholders, but also by the desire of the companies' attainment of its competitive advantage over its competitors, having a stable working environment and building a happy, productive and healthy workforce. In research it was identified that these factors have impulse multinational oil companies in Africa (Nigeria) to put in CSR activities. And this may not be case of Nigeria only. ike consumers, employees, investors, business suppliers and customers which may drive CSR in the companies of the world (Brammer, et al., 2007). May be these market drivers independently drive the practice of CSR. The social organizations like NGOs or welfare committees may pressurize the companies to be responsible to the society. Paradoxically, apparently this has sometimes led to NGOs (e.g. community organizations, international campaign groups) and companies or business associations entering into partnerships to encourage, develop, manage and report CSR (Newell, 200, Doh and Guay, 2006). Government in the present world is playing a vital role for implementing CSR in the companies. For example, in the education sector government plays an effective role as a pioneer of CSR activities. It not only promotes a policy structure for national education and CSR but also designate CSR practices in the national education. This in turn presents a significant opportunity for businesses to "lead from behind" (Petkoski and Twose, 2003). The work of the CSR practice has generally rein-forced the relevance of the four public sector roles in strengthening CSRmandating, facilitating, partnering, and endorsing. (Ward, H. 2004).Collectively organizations are signing up to organizations to advance CSR i.e. the UN Global Compact and the International Business Leaders Forum and even few companies are going for international compliance reporting for example, the Global Reporting Initiative. Individually, companies are developing corporate codes to enable them to better articulate and embed their CSR across various countries of their operations and across their global supply chains (Kolk, 2005). It is also observed that the companies who cross borders are more attentive to their CSR than companies operating only in one country, as well as being sensitive to local CSR agendas (Chapple and Moon, 2005). The top position of an organization and the quality of the person who is at the top level of management can embrace the practice of CSR in the organizations Campbell stated that the experiences of a corporate manager in the educational sites influence CSR implementation (Campbell, 2007). Waldman et al. emphasizes on the personal competencies of the top managers for implementation of the CSR. He argues that the CEO-a firm's key decision maker, by his personal qualities and supreme characteristics formulates corporate procedure in order to extend firm's CSR initiatives(Waldman et al., 2006a) and the CEO is in a prime position to influence CSR strategy and practice (Waldman and Siegel, 2008; Cassells and Lewis, 2011).

\section{CONCLUSION:}

The companies are now keen to implement CSR in their organizations; especially many of the big companies are already instigating the CSR practices and having the taste of the sweet fruit of it. But for a successful implementation of the CSR in the company the managers should have to have the knowledge about the fundamentals of CSR. At the same time more researches should also take place on how the companies can utilize this concept more comfortably. Fundamentally CSR teaches us not to leave every traditional activity, but to do the things in the different way which will benefit the people, the planet and the organizations' ultimate purpose.

\section{REFERENCES:}

[1] Chopra, Abha, and Shruti Marriya. "Corporate Social Responsibility and Education in India." (2014).

[2] Waddock, S.: 2004, 'Parallel universes: companies, academics, and the progress of corporate citizenship', Business and Society Review 109, 5-42.

[3] Waldman D, Siegel D, Javidan M. 2006a. Components of CEO transformational leadership and corporate social responsibility. Journal of Management Studies43: 1703-1725.

[4] Waldman D, Siegel D. 2008. Defining the socially responsible leader. The Leadership Quarterly19: 117131.

[5] Du, Shuili, Valérie Swaen, Adam Lindgreen, and Sankar Sen. "The roles of leadership styles in corporate social responsibility."Journal of business ethics 114, no. 1 (2013): 155-169.

[6] Sriramesh, K., Ng, C. W., Ting, S. T., \&Wanyin, L. (2007). Corporate social responsibility and public relations. The Debate over Corporate Social Responsibility (ed. May S., Cheney, G. and Roper J.), 119134.

[7] Nasrullah, N.M. and Rahim, M.M., 2014. CSR in private enterprises in developing countries. Evidences from the Ready-Made Garments Industry in Bangladesh. 
[8] Industry Canada. (2009). Corporate social responsibility guide project leader. Retrieved 30 August 2012 from http://www.ioc.gc.ca/eic/site/csr-rse.ns/eng/rs00128.html

[9] Moon, J., 2005. United Kingdom. In Corporate social responsibility across Europe (pp. 51-65). Springer Berlin Heidelberg.

[10] Crook, C.: 2005, 'The Good Company', Economist37, January, 41-31.

[11] Cramer, J., A. van der Heijden and J. Jonker: 2006, 'Corporate Social Responsibility: Making Sense through Thinking and Acting', Business Ethics: A European Review15 (4), 380-389.

[12] Elkington, J., 2004. Enter the triple bottom line. The triple bottom line: Does it all add up, 11(12), pp.116.

[13] Campbell J. 2007. Why would corporations behave in socially responsible ways? An institutional theory of corporate social responsibility. Academy of Management Review32: 946-967.

[14] Matten, D. and J. Moon: 2008, "Implicit" and "Explicit" CSR: A Conceptual Framework for a Comparative Understanding of Corporate Social Responsibility', Academy of Management Review33, 404-424

[15] Ward, Halina. Public sector roles in strengthening corporate social responsibility: taking stock. Washington, DC: World Bank, 2004.

[16] Carroll, A. (2000), Ethical Challenges for Business in the New Millennium: Corporate Social Responsibility and Models of Management Morality, Business Ethics Quarterly, 10 (1), pp. 33-42.

[17] Maignan, Isabelle, and O.C. Ferrell (2001) Corporate Citizenship as a Marketing Instrument: Concepts, Evidence, and Research Directions, European Journal of Marketing, 35(3/4): pp. 457-484.

[18] European Union. (2002). Green paper promoting a European framework for corporate social responsibility.

[19] McWilliams, A. and Siegel, D. 2000. 'Corporate social responsibility and financial performance: correlation or misspecification?’ Strategic Management Journal, 21:5, 603-609.

[20] European Commission. Directorate-General for Employment, 2001. Promoting a European Framework for Corporate Social Responsibility: Green Paper. Office for Official Publications of the European Communities.

[21] OECD (2001): Corporate social responsibility: Partners for progress, Paris: OECD.

[22] Schaltegger, S. and Burritt, R., 2005. 5. Corporate sustainability. The International Yearbook of Environmental and Resource Economics 2005/2006, p.185.

[23] Kuada, John, and Robert E. Hinson. "Corporate social responsibility (CSR) practices of foreign and local companies in Ghana."Thunderbird International Business Review 54, no. 4 (2012): 521-536.

[24] McDonald, L. M., \& Rundle-Thiele, S. (2008). Corporate social responsibility and bank customer satisfaction: A research agenda.

[25] Calabrese, Armando, and Flavia Lancioni. "Analysis of Corporate Social Responsibility in the service sector: does exist a strategic path?"Knowledge and Process Management 15, no. 2 (2008): 107-125.

[26] Pimpa, Nattavud. "Multinational corporations: Corporate social responsibility and poverty alleviation in Thailand."School of Management (2011).

[27] WBCSD (2002) 'Corporate Social Responsibility: The WBCSD‘s journey' [Online]. World Business Council for Sustainable Development, [quot. 14 December 2016]. Available on World Wide Web: http://www.wbcsd.org/

[28] Waddock, S.A., Bodwell, C. and Graves, S.B., 2002. Responsibility: The new business imperative. The Academy of Management Executive, 16(2), pp.132-148..

[29] McWilliams A, Siegel D. 2001. Corporate social responsibility: A theory of the firm perspective. Academy of Management Review26: 117-127.

[30] Waldman, D.A., de Luque, M.S., Washburn, N., House, R.J., Adetoun, B., Barrasa, A., Bobina, M., Bodur, M., Chen, Y.J., Debbarma, S. and Dorfman, P., 2006. Cultural and leadership predictors of corporate social responsibility values of top management: A GLOBE study of 15 countries. Journal of International Business Studies, 37(6), pp.823-837.

[31] Adam, A.M. and Shavit, T. 2008. 'How can a ratings-based method for assessing corporate social responsibility (CSR) provide an incentive to firms excluded from socially responsible investment indices to invest in CSR?' Journal of Business Ethics, 82:4, 899-905.

[32] Handelman, J.M. and S.J. Arnold: 1999, 'The role of marketing actions with a social dimension: Appeals to the institutional environment', Journal of Marketing 63, 33-48.

[33] Palazzo, G. and A.G. Scherer: 2006, 'Corporate legitimacy as deliberation: A communicative framework', Journal of Business Ethics 66, 71-88.

[34] Sen, S. and C.B. Bhattacharya: 2001, 'Does doing good always lead to doing better? Consumer reactions to corporate social responsibility', Journal of Marketing Research 38, 225-243. 
[35] Tudev, O. and Lkhagvasuren, E., 2011. The implementation of Corporate Social Responsibility in Mongolian business sector. Journal on Efficiency and Responsibility in Education and Science, 4(2), p.89.

[36] Inyang, B.J., 2013. Small-and medium-sized enterprises engagement in CSR. In Encyclopedia of Corporate social responsibility (pp. 2160-2167). Springer Berlin Heidelberg.

[37] Massoud, J.A., 2010. Exploring small and medium enterprise social responsibility in Argentina.

[38] Ditlev-Simonsen C, Midttun A. 2011. What motivates managers to pursue corporate responsibility? A survey among key stakeholders. Corporate Social Responsibility and Environmental Management18:2538.

[39] Basu K, Palazzo G. 2008. Corporate social responsibility: A process model of sensemaking.Academy of Management Review33: 122-136.

[40] McWilliams A, Siegel D, Wright P. 2006. Corporate social responsibility: Strategic implications. Journal of Management Studies43:1-18.

[41] Brammer, Stephen, Andrew Millington, and Bruce Rayton. "The contribution of corporate social responsibility to organizational commitment."The International Journal of Human Resource Management 18.10 (2007): 1701-1719.

[42] Doh JP, Guay TR. 2006. Corporate social responsibility, public policy, and NGO activism in Europe and the United States: an institutional-stakeholder perspective. Journal of Management Studies 43(1): 47-73.

[43] Newell, Peter. "Environmental NGOs and globalization: The governance of TNCs." Global social movements (2000): 117-33.

[44] Petkoski, D. and Twose, N., 2003. Public Policy for Corporate Social Responsibility. WBI Series on Corporate Responsibility, Accountability and Sustainable Competitiveness. The World Bank Institute: Washington, DC.

[45] Kolk A. 2005. Corporate social responsibility in the coffee sector: the dynamics of MNC responses and code development. European Management Journal 23(2): 228-236

[46] Chapple, W. and Moon, J., 2005. Corporate social responsibility (CSR) in Asia a seven-country study of CSR web site reporting. Business \& society, 44(4), pp.415-441.

[47] Cassells S, Lewis K. 2011. SMEs and environmental responsibility: do actions reflect attitudes?Corporate Social Responsibility and Environmental Management18: 186-199. 